\title{
DAMPAK 7-DAY RESERVE REPO RATE BANK INDONESIA DAN NILAI TUKAR RUPIAH TERHADAP PROFITABILITAS PERBANKAN PERIODE 2017-2019
}

\author{
Agus Salihin \\ Universitas Islam Negeri UIN Sunan Kalijaga Yogyakarta \\ Email:agussalihin03@gmail.com
}

\begin{abstract}
The purpose of this study was to determine the Impact of the 7-Day Reserve Repo Rate of Bank Indonesia and the Rupiah Exchange Rate on the Profitability of the 2017-2019 Banking Period ". This study uses quantitative methods with panel data model estimation models. This study uses secondary data in the form of monthly financial statements obtained from Bankside Bank Indonesia with the 2017-2019 time period. While the data analysis technique uses the Classic Assumption Test, multiple linear regression test with the help of the SPSS program. Based on the results of the analysis it can be explained that from the classic assumption test there are normally distributed data and there are no problems of multicollinearity and heteroscedasticity. While the results of multiple linear regression analysis can be explained that the 7-Day Reserve Repo Rate variable of Bank Indonesia and the Rupiah Exchange Rate has a Positive Effect on the Profitability of the 2017-2019 Banking Period either partially or simultaneously. As for the results of the test of the coefficient of determination of the 7-Day Reserve Repo Rate of Bank Indonesia and the Rupiah Exchange Rate, it can affect the Banking Profitability of $32.5 \%$.
\end{abstract}

Keywords: 7-Day Reserve Repo Rate, Exchange Rate, Banking Profitability

\begin{abstract}
Abstrak
Penelitian ini bertujuan untuk mengetahui Dampak 7- Day Reserve Repo RateBank Indonesia dan Nilai Tukar Rupiah Terhadap Profitabilitan Perbankan Priode 2017-2019”. Penelitian ini menggunakan metode kuantitatif dengan estimasi model regresii data panel. Penelitian ini menggunakan data sekunder berupa Laporan Keuangan bulanan yang diperoleh dari Webside Bank Indonesia dengan priode waktu 2017-2019. Sedangkan teknik analisis data menggunakan Uji Asumsi Klasik, Uji regresi linier berganda dengan bantuan program SPSS. Berdasarkan hasil analisis dapat dijelaskan bahwa dari uji asumsi klasik terdapat data terdistribusi secara Normal dan tidak terdapat masalah Multikolinieritas dan Heteroskedastisitas. Sedangkan dari hasil analisis regresi linier berganda dapat di jelaskan bahwa variabel 7-Day Reserve Repo Rate Bank Indonesia dan Nilai Tukar Rupiah Berpengaruh Positif terhadap Profitabilitas Perbankan Priode 2017-2019 baik secara parsial maupun secara simultan. Adapaun dari hasil uji koefisien determinasi variabel 7-Day Reserve Repo RateBank Indonesia dan Nilai Tukar Rupiah dapat mempengaruhi Profitabilitas Perbankan sebesar $32,5 \%$.
\end{abstract}

Kata Kunci :7-Day Reserve Repo Rate, Kurs, Profitabilitas Perbankan

Website: http://jurnal.radenfatah..ac.id/index.php/ieconomics 
I-Economic: A Research Journal on Islamic Economics

ISSN 2548-5601, e-ISSN 2548-561X

Vol 6. No 1. Juni 2020

\section{PENDAHULUAN}

Perkembangan dunia keuangan khususnya perbankan diera tahun 2000-an telah memasuki masa kebangkitan dari keterpurukan setelah diera krisis ekonomi tahun 1998 yang lalu. Kemajuan ini ditunjukkan dunia perbankan melalui jumlah dana yang mampu diserap dari masyarakat dan disalurkan kembali ke masyarakat.1Kegiatan ini merupakan salah satu fungsi kinerja Bank.Untuk melihat sejauh mana kinerja bank dapat menjalankan fungsinya maka diperlukan sebuah penilaian.Penilaian kinerja keuangan bank merupakan faktor penting yang harus di jalankan guna mengetahui sampai sejauh mana kinerja bank dapat berjalan dengan baik atau belum.Maka penilaian kinerja bank dapat dilihat dari laporan keuangan tahunan yang berasal dari perhitungan rasio keuangan.2

Selain itu, dengan adanya laporan keuangan yang dijadikan sebuah penilaian dapat memberikan informasi tentang jumlah kekayaan (asset), jenis kekayaan, laporan laba rugi, permodalan dan prestasi yang dicapai perusahaan.Dimana keempat indikator tersebut merupakan tolok ukur profitabilitas bank.Profitabilitas yaitu kemampuan bank untuk mendapatkan keuntungan/laba dengan efektif dan efisien. Ukuran profitabilitas yang digunakan dalam penelitian ini adalah Return on Asset (ROA).

Anthanasoglou mengatakan bahwa Profitabilitas Bank dipengaruhi oleh dua faktor yaitu faktor internal dan eksternal. Faktor internal yang dapat mempengaruhi profitabilitas bank adalah faktor mikro atau faktor spesifik bank yang menentukan profitabilitas. Sedangkan faktor eksternal merupakan faktor dari luar yang tidak memiliki hubungan dengan pihak bank namun secara tidak lansung memberikan efek bagi kinerja lembaga keuangan.Salah satu faktor eksternal yang perlu diperhatikan adalah tingkat suku bunga dan nilai tukar rupiah.3

Pada tanggal 19 Agustus 2016, Bank Indonesia (BI) menerapkan BI 7-Day Reserve Repo Rate sebagai suku bunga BI yang baru. Tujuan penerapan BI 7-Day Reserve Repo Rate adalah untuk memperkuan efektivitas kebijakan moneter, sehingga lebih reponsif terhadap

1 Kasmir, Bank dan Lembaga Keuangan Lainnya, cet.17 (Jakarta: Rajawali Pers, 2016), hlm.2

2 Millatina Arimi, Analisis Faktor-Faktor yang Mempengaruhi Profitabilitas Perbankan (Studi pada Bank Umum yang Listed di Bursa Efek Indonesia Tahun 2007-2010), Skripsi Universitas Diponegoro, Semarang, 2012.

3 Panayiotis P. Athanasoglou, Sophocles N. Brissimis, and Matthaios D. Delis, "Bank-Specific, IndustrySpecific and Macroeconomic Determinants of Bank Profitability," Journal of International Financial Markets, Institutions and Money 18, no. 2 (April 1, 2008): 121-136.

Website: http://jurnal.radenfatah..ac.id/index.php/ieconomics 
perubahan tingkat suku bunga kebijakan maupun dampaknya terhadap suku bunga pasar uang dan perbankan.4 Dalam menentukan perubahan suku bunga kebijakan, terdapat sejumlah kriteria yang harus dipenuhi, yaitu bersifat transaksional (antara BI dengan perbankan), memiliki pasar yang relatif dalam, dan memiliki hubungan yang kuat dengan sasaran operasional kebijakan moneter.

Dari penguatan operasi moneter ini, terdapat tiga dampak utama yang diharapkan, pertama menguatnya sinyal kebijakan moneter dengan suku bunga (Reserve) Repo Rate 7 hari sebagai acuan utama di pasar keuangan. Hal ini diharapkan akan menambah atraktif kondisi pasar keuangan Indonesia. Kedua, meningkatnya efektivitas transmisi kebijakan moneter melalui pengaruhnya pada pergerakan suku bunga pasar uang dan suku bunga perbankan.Ketiga, terbentuknya pasar keuangan yang lebih dalam, khususnya transaksi dan struktur bunga di pasar uang antarbank (PUAB) untuk tenor 3 bulan hingga 12 bulan. Penguatan operasi moneter akan disertai dengan langkah-langkah untuk percepatan pendalaman pasar uang.5 Selain dariitu, penerapan BI 7-Day Reserve Repo Rate pada pasar uang akan berdampak pada profitabilitas Bank.6

Selain dari faktor 7-Days Reverse Repo Rate, nilai tukar rupiah juga dapat mempengaruhi profitailitas perbankan. Hal inidisebabkan karena bank juga memberikan jasa jual beli valuta asing.Dalamkegiatan transaksi nilai tukar mata uang asing selalu menawarkan dua harga nilai tukar diantaranya harga jual dan harga beli yang mana dalam keadaan normal teransaksi tersebut memberikan keuntungan berupa selisih antara harga jual dan harga beli.7 Kegiatan inilah yang menjadi perhatian bank karna hal tersebut dapat mempengaruhi tingkat profitabilitas bank.Pernyataan ini dibuktikan oleh penelitian yang dilakukan oleh Amalia, memberikan hasil bahwa kurs mempunyai pengruh yang signifikan terhadap profitabilitas

4 Slamet Widodo et al., "7-Day Reserve Repo Rate, Acuan Suku Bunga Baru Bank Indonesia” buletin APBN 01, no. 17 (2016): 12.

5 Ibid.

6 Sofyan Marwansyah and Sri Rusiyati, "Dampak Kebijakan BI Rate Repo 7 Days terhadap Kinerja Bank Pemerintah," Jurnal Ecodemica: Jurnal Ekonomi, Manajemen, dan Bisnis 3, no. 2 (September 9, 2019): 248-256.

7 Febrina Dwijayanthy and Prima Naomi, "Analisis Pengaruh Inflasi, BI Rate, Dan Nilai Tukar Mata Uang Terhadap Profitabilitas Bank Periode 2003-2007 [English: Analysis of Effect of Inflation, BI Rate, and Exchange Rate on Bank Profitability (Period 2003-2007)]," Jurnal KARISMA 3, no. 2 (April 1, 2009): 87-98.

Website: http://jurnal.radenfatah..ac.id/index.php/ieconomics 
bank.8 Kondisi inilah membuat peneliti tertarik untuk menggali lebih dalam terkait dengan dampak 7-day resrve repo rate dan nilai tukar rupiah pada profitabilitas perbankan. Hingga penelitian ini bertujuan untuk mengetahui "Dampak Suku Bunga 7-Day Reserve Repo RateBankIndonesia dan Nilai Tukar RupiahTerhadap Profitabilitan Perbankan Priode 20172019”.

\section{KERANGKA TEORI}

\section{Return on Asset (ROA)}

Return on Asset (ROA) merupakan rasio yang digunakan untuk mengukur kemampuan manajmen bank dalam memproleh profitabilitas dan mengelola tingkat efisiensi usaha bank secara keseluruhan. Menurut Lukman Returen on Asset merupakan "pengukuran kemampuan perusahaan secara keseluruhan didalam menghasilkan keuntungan dengan jumlah keseluruhan aktiva yang tersedia didalam perusahaan".9

Jika nilai ROA yang semakin mendekati 1, maka semakin baik profitabilitas perusahaan karena setiap aktiva yang ada dapat menghasilkan laba. Dengan kata lain jika semakin tinggi nilai ROA maka kinerja keuangan perusahaan semakin baik. Selain itu, perusahaan yang memiliki profitabilitas tinggi akan menarik investor yang menginvestasikan dananya pada perusahaan tersebut karena diyakini perusahaan akan memberikan returen yang tinggi pula.10

\section{BI 7-Day Reseve Repo Rate}

Pada tanggal 19 Agustus 2016 Bank Indonesia (BI) menggunakan 7-day Reserve Repo Rate sebagai suku bunga acuan yang baru. 7-day Reserve Repo Rate merupakan instrumen moneter yang digunakan BI untuk memudahkan merefleksikan kebijakannya di pasar keuangan.Instrumen baru ini mendekatkan jarak antara suku bunga pasar uang dengan suku bunga kebijakan.Selain itu, instrumen 7-day Reserve Repo Rate juga ditujukan untuk memperdalam pasar keuangan di Indonesia.Dengan memperdalam kondisi pasar keuangan di

8Amalia Nuril Hidayati, "Pengaruh Inflasi, Bi Rate Dan Kurs Terhadap Profitabilitas Bank Syariah Di Indonesia," An-Nisbah: Jurnal Ekonomi Syariah 1, no. 1 (October 10, 2014): $72-97$.

9 Lukman Syamsuddin, Manajmen Keuangan Perusahaan, (Jakarta: PT Raja Grafindo Persada), hlm. 63

10 Debby Wulandari, Pengaruh Tingkat Suku Bunga, Pertumbuhan Ekonomi (PDB) dan Return on Asset (ROA) Terhadap Investasi Saham Syariah, Skripsi, UIN Sunan Kalijaga Yogyakarta, 2016.

Website: http://jurnal.radenfatah..ac.id/index.php/ieconomics 
Indonesia, aktivitas di pasar keuangan menjadi lebih sering.Kelebihan uang di BI dapat dialihgunakan sehingga pasar keuangan makin dalam karena mereka bergerak di waktu jangka pendek.Upaya ini juga diharapkan bisa menjadi model bagi perbankan.Karena untuk kepentingan interaksi keuangan antar bank, maka BI 7-Day Repo Rate bisa digunakan sebagai acuan perbankan.11

Perubahan suku bunga kebijakan baru dilakukan karena kondisi makro ekonomi yang mendukung, seperti inflasi yang rendah dan stabil, pertumbuhan ekonomi yang relative baik serta indicator-indikator ekonomi yang kondusif.Tujuan perubahan ini adalah untuk memperkuat efektivitas kebijakan moneter, sehingga lebih responsive terhadap perubahan tingkat suku bunga kebijakan.7-day Repo Rate mengacu pada instrument operasi moneter yang aktif ditransaksikan antara BI dengan perbankan (transaksional) setiap hari.Jadwal pengumuman 7-day Repo Rate yaitu sebulan sekali sedudah Rapat Dewan Gubernur (RDG). Setelah pengumuman hasil RDG setiap bulannya 7-day Repo Rateakan tetap sama selama sebulan sampai pengumuman RDG bulan berikutnya.12

Berikut data historical pergerakan BI 7-Days Reverse Repo Ratepada tabel 1.1 dibawah ini:

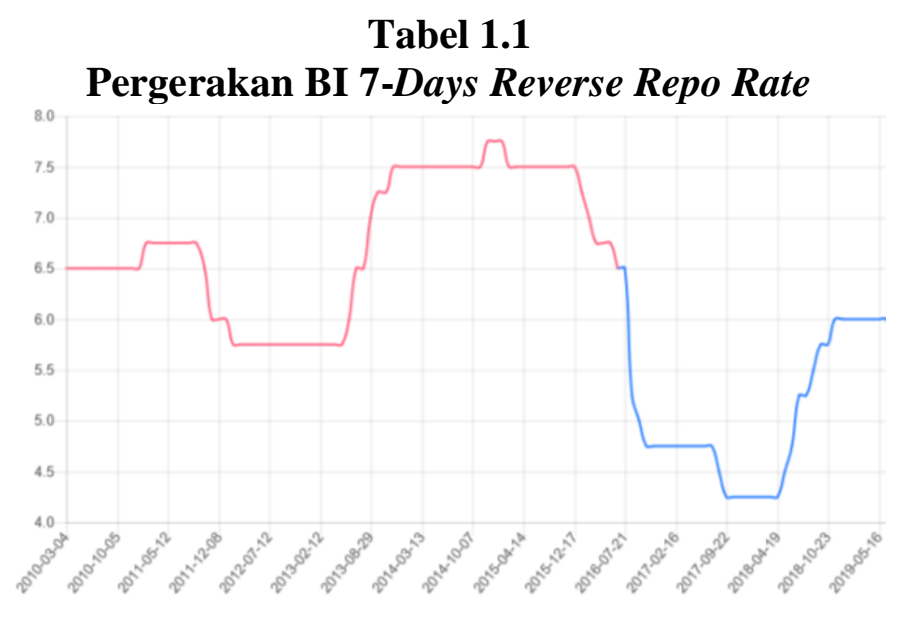

Sumber: Bank Indonesia

BI 7-dav (Reverse) Reno Rate

Berdasarkan data historical diatas dapat dilihat bahwa BI 7-Days Reverse Repo Ratememiliki pergerakan yang cukup signifikan. Namun padat tahun 2018-2019 trennya

11 Widodo et al., "7-Day Reserve Repo Rate, Acuan Suku Bunga Baru Bank Indonesia" 12https://www.bi.go.id

Website: http://jurnal.radenfatah..ac.id/index.php/ieconomics 
selalu meningkat hingga pada akhir bulan Desember 2019 menutup suku bunga acuan (BI 7Days Reverse Repo Rate) sebesar (6.00) basis point.13

\section{Nilai Tukar Rupiah}

Nilai tukar rupiah merupakan persentase dari tingkat harga nilai tukar mata uang dengan mata uang lainnya dan digunakan dalam berbagai transaksi diantaranya transaksi perdagangan internasional, turisme, investasi internasional, ataupun aliran uang jangka pendek antar negara.Adiwarman karim berpendapat bahwa nilai tukar uang atau kurs adalah catatan harga pasar dari mata uang asing dalam harga mata uang domestik atau resiprokalnya yaitu harga mata ang domestik dalam mata uang asing.14 Kesetabilan pergerakan nilai Kurs menjadi sangat penting, terlebih bagi perusahaan yang aktif dalam kegiatan ekspor impor yang tidak dapat terlepas dari penggunaan mata uang asing yaitu Dollar Amerika Serikat sebagai media transaksi atau mata uang yang paling sering digunakan dalam perdagangan global.

Berikut data historical pergerakan nilai tukar rupiah/ Kurs pada tabel 1.2 dibawah ini:

Tabel 1.2

\section{Pergerakan Nilai Tukar Rupiah}

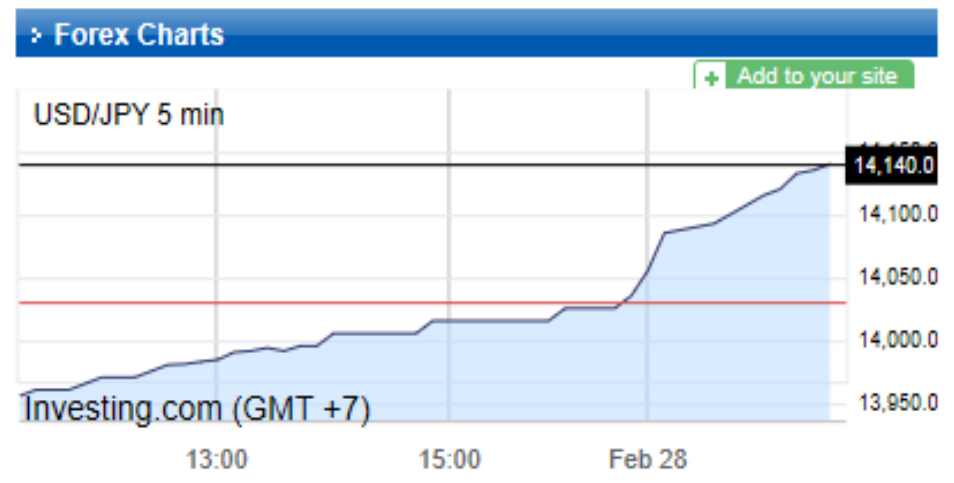

Sumber: Investing.com

Berdasarkan data historical pada tabel 1.2 diatas dapat dilihat bahwa pergerakan nilai tukar rupiah mengalami tren yang selalu meningkat.Hingga pada akhir bulan Desember 2019 nilai tukar rupiah terhadap dolar berada pada $14,140.0 .15$

13https://pusatdata.kontan.co.id

14 Adiwarman Karim, Ekonomi Makro Islam, (Jakarta: PT Raja Grafindo Persada, 2008), hlm. 157 15https://www.investing.com/.

Website: http://jurnal.radenfatah..ac.id/index.php/ieconomics 


\section{HIPOTESIS PENELITIAN}

Berdasarkan latar belakang dan kajian teori diatas maka penelitian ini mengajukan hipotesis sebagai dugaan sementara atas permasalahan-permasalahan yang ada. Adapun hipotesis yang dapat peneliti ajukan adalah sebagai berikut:

H1 :7-Day Resreve Repo Rate Bank Indonesia Berpengaruh Positif Terhadap Profitabilitas Perbankan Priode 2017-2019.

H2 :Nilai Tukar Rupiah Berpengaruh Positif Terhadap Profitabilitas Perbankan Priode 2017-2019.

H3 :7-Day Resreve Repo Ratedan Nilai Tukar Rupiah Berpengaruh Positif Terhadap Profitabilitas Perbankan Priode 2017-2019.

\section{METODE PENELITIAN}

Penelitian ini menggunakan metode kuantitatif dengan estimasi model regsegi data panel.Populasi dalam penelitian ini adalah seluruh perbankan yang tercatat di Bursa Efek Indonesia (BEI).Sedangkan teknik sampling menggunakan Proporsive Samping dimana teknik ini mengambil sampel berdasarkan kriteria tertentu.Adapun kriteria pengambilan sampel yaitu; Pertama, Perbankan yang telah terdaftar di bursa efek Indonesia sejak tahun 2017-2019.Kedua, Laporan Keuangan yang telah di audit sejak tahun 2017-2019.

Penelitian ini menggunakan data sekunder berupa Laporan Keuangan bulanan yang diperoleh dari Webside Bank Indonesia dengan priode waktu 2017-2019. Sedangkan teknik analisis data menggunakan Uji Asumsi Klasik, Uji regresi linier berganda dengan bantuan program SPSS. Adapun rumus dasar regresi linier berganda adalah sebagai berikut:

$$
\mathrm{Y}=\alpha+\beta 1 \mathrm{X} 1+\beta 2 \mathrm{X} 2+\beta 3 \mathrm{X} 3
$$

Dimana :

$$
\begin{array}{ll}
\mathrm{Y} & =\text { Return on Asset }(\mathrm{ROA}) \\
\mathrm{A} & =\text { Konstanta } \\
\beta 1-\beta 4 & =\text { Koefisien Regresi Variabel } \\
\mathrm{X} 1 & =\text { Suku Bunga 7-Day Reseve Repo Rate } \\
\mathrm{X} 2 & =\text { Nilai Tukar Rupiah (KURS) }
\end{array}
$$

Website: http://jurnal.radenfatah..ac.id/index.php/ieconomics 
Penelitian ini menggunakan tingkat signifikasi $(\alpha) 5 \%$, sehingga jika nilai signifikasi lebih kecil dari 5\% (<5\%) maka koefisien regresi berpengaruh positif signifikan.

\section{HASIL PENELITIAN}

\section{Uji Asumsi Klasik}

\section{a. Uji Normalitas}

Uji normalitas digunakan untuk mengetahui apakah populasi data berdistribusi normal atau tidak. Dikatakan data normal jika membandingkan nilai Asymp.Sig (2Tailend) dengan nilai alpha 5\% sehingga apabila nilai Asymp.Sig (2-Tailend) lebih besar 0,05 maka dapat disimpulkan bahwa data tersebut berasal dari populasi yang terdistribusi secara normal. Adapun hasil uji normalitas dapat dilihat pada table 1.3 dibawah ini:

Tabel 1.3

Hasil Uji Normalitas

One-Sample Kolmogorow-Smirnow Test

\begin{tabular}{|ll|r|}
\hline & & $\begin{array}{r}\text { Unstandardiz } \\
\text { ed Residual }\end{array}$ \\
\hline Normal Parameters & Mean & 60 \\
Most Extreme Differences & Std. Deviation & .0000000 \\
& Absolute & 40.42078744 \\
& Positive & .097 \\
Kolmogorov-Smirnov Z & Negative & .084 \\
Asymp. Sig. (2-tailed) & & -.097 \\
\end{tabular}

Sumber: SPSS Data diolah

Berdasarkan hasil uji normalitas diatas terlihat bahwa nilai Asymp.Sig. (2tailend) sebesar 0,827, dimana nilai tersebut ebih besar dari 0,05. Maka dapat disimpulkan bahwa data terdistribusi secara normal.

\section{b. Uji Multikolinieritas}

Multikolinieritas dapat diketahui dari nilai toleransi dan variance inflation faktor (VIF). Nilai umum yang dipakai untuk menunjukkan ada tau tidaknya multikolinieritas adalah nilai tolerance $>0.10$ atau sama dengan $\mathrm{VIF}<10$. Adapun hasil uji multikolinieritas dapat dilihat pada tabel 1.4dibawah ini:

Website: http://jurnal.radenfatah..ac.id/index.php/ieconomics 
Tabel 1.4

\section{Hasil Uji Multikolinieritas} Loenlicients

\begin{tabular}{|c|c|c|c|c|c|c|c|c|}
\hline \multirow[b]{2}{*}{ Model L } & & \multicolumn{2}{|c|}{ Unstandaradized Coefticents } & \multirow{2}{*}{$\begin{array}{l}\text { Standardiced } \\
\text { Coeficients } \\
\text { Beta }\end{array}$} & \multirow[b]{2}{*}{1} & \multirow[b]{2}{*}{ Sila. } & \multicolumn{2}{|c|}{ Collinearity statistich } \\
\hline & & $B$ & sid Earor & & & & Tolerance & $\| F$ \\
\hline 1 & (Constant) & 753.948 & 860.033 & & 8764 & .000 & & \\
\hline & B|7.day Reno Rate & .097 & .018 & .706 & 5.475 & .000 & .687 & 1.455 \\
\hline & KURG & .027 & .008 & .467 & .3 .617 & .001 & .687 & 1.455 \\
\hline
\end{tabular}

Sumber: SPSS Data diolah

Hasil nilai VIF yang diperoleh dalam table menunjukkan variabel bebas dalam model regresi tidak saling berkorelasi. Diperoleh nilai VIF untuk masing-masing variabel bebas kurang dari 10 dan nilai tolerance berada di atas 0.10 . maka dapat disimpulkan bawa tidak terdapat masalah multikolinieritas diantara sesama variabel bebas dalam model regresi yang dibentuk.

\section{c. Uji Heteroskedastisitas}

Model regresi yang baik adalah tidak terjadi heteroskedastisitas. Untuk melihat apakah terjadi heteroskedastisitas atau tidak dapat dilihat pada titik-titik menyebar diatas dan dibawah angka 0 pada sumbu Y. berikut hasil uji heteroskedastisitas pada tabel 1.5 dibawah ini:

Tabel 1.5

\section{Hasil Uji Heteroskedastisitas}

Dependent Variable: ROA

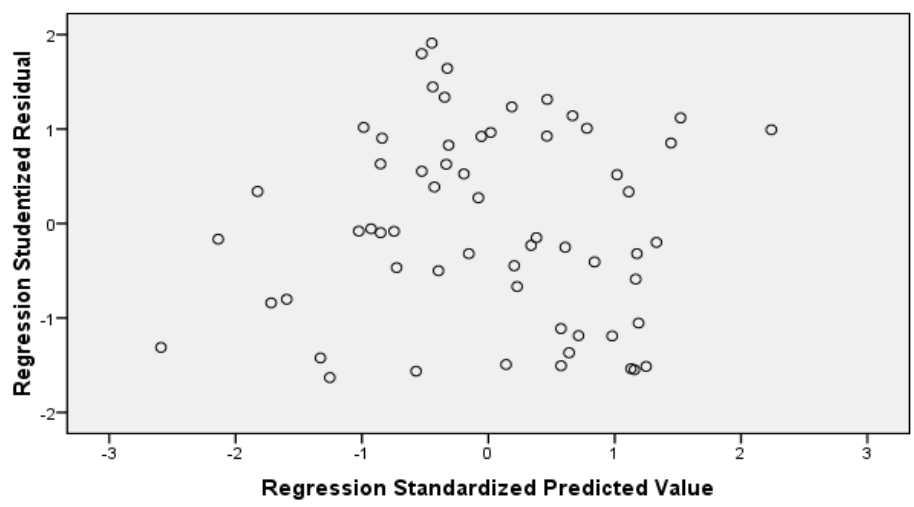

Sumber: SPSS Data diolah

Website: http://jurnal.radenfatah..ac.id/index.php/ieconomics 
Berdasarkah hasil analisis diatas dapat dilihat bahwa terjadinya titik-titik yang menyebar diatas dan dibawah nol pada sumbu Y, sehingga dapat disimpulkan bahwa tidak terjadi masalah heteroskedastisitas pada model regresi

\section{Analisis Regresi Linier Beganda}

\section{a. Uji t Statistic}

Uji t statistic merupakan pengujian sebuah variabel independen (X) yang secara parsial dapat mempengaruhi variabel dependen (Y).dalam uji t statistic terdapat 4 variabel yang diuji diantaranya 3 variabel independen $(\mathrm{X})$ dan 1 variabel dependen (Y). adapun hasil uji t statistic dapat dilihat pada tabel 1.6 dibawah ini.

Tabel 1.6

\section{Hasil Uji t Statistik}

\begin{tabular}{|c|c|c|c|c|c|c|c|c|}
\hline \multirow[b]{2}{*}{ Modele } & & \multicolumn{2}{|c|}{ Unsiandarlized Coeficicints } & \multirow{2}{*}{$\begin{array}{c}\text { Standardiced } \\
\text { Coeficients } \\
\text { Beta } \\
\end{array}$} & \multirow[b]{2}{*}{$t$} & \multirow[b]{2}{*}{ Sia. } & \multicolumn{2}{|c|}{ Collinearity Staistics } \\
\hline & & $B$ & Sto. Errof & & & & Tolerance & UF \\
\hline \multirow[t]{3}{*}{1} & (Constant) & 753.948 & 86.033 & & 8.764 & .000 & & \\
\hline & B17.0vay Repo Rate & .097 & .018 & .706 & 5.475 & .000 & .687 & 1.455 \\
\hline & KURS & .027 & .008 & .467 & .3 .617 & .001 & .687 & 1.455 \\
\hline
\end{tabular}

Sumber: SPSS Data diolah

a. Pengaruh 7-day Reserve Repo RateBank Indonesia Terhadap Returen on Asset (ROA)

Berdasarkan hasil uji $\mathrm{t}$ statistic diatas dapat diketahui bahwa nilai signifikan 7-day Reserve Repo Rate sebesar 0,000 yang berarti sig 0,000<0,05. Hasil ini dapat di ketahui bahwa (H1) diterima, yang artinya bahwa pengujian secara parsial terdapat pengaruhpositif antara7-day Reserve Repo RateBank Indonesia terhadap Profitabilitas Perbankan Priode 2017-2019.

b. Pengaruh Nilai Tukar RupiahTerhadap Returen on Asset (ROA)

Website: http://jurnal.radenfatah..ac.id/index.php/ieconomics 
Berdasarkan hasil uji $\mathrm{t}$ statistic diatas dapat diketahui bahwa nilai signifikan Nilai Tukar Rupiah sebesar 0,001 yang berarti sig 0,001<0,05. Hasil ini dapat di ketahui bahwa $(\mathrm{H} 2)$ diterima, yang artinya bahwa pengujian secara parsial terdapat pengaruh positif antara Nilai Tukar Rupiah terhadap Profitabilitas Perbankan Priode 2017-2019.

\section{b. Uji F Statistic}

Uji F Statistic merupakan pengujian suatu variabel yang secara simultan antara variabel independen (X) dengan variabel dependen (Y). Adapun hasil uji $\mathrm{F}$ Statistic dapat dilihat pada tabel 1.7 dibawah ini:

Tabel 1.7 Hasil Uji F Statistic

ANOVA

\begin{tabular}{|c|c|c|c|c|c|c|}
\hline Made & & $\begin{array}{c}\text { Sum of } \\
\text { Squares } \\
\end{array}$ & df & Mean Square & $\mathrm{F}$ & Sig. \\
\hline \multirow[t]{3}{*}{1} & Regression & 51451.805 & 2 & 25725.902 & 15.212 & $.000^{2}$ \\
\hline & Residual & 96396.563 & 57 & 1691.168 & & \\
\hline & Total & 147848.368 & 59 & & & \\
\hline
\end{tabular}

Sumber: SPSS Data diolah

Berdasarkan hasil uji F statistic pada tabel 1.2 diatas dapat diketahui bahwa nilai signifikansi sebesar 0,000 yang artinya sig 0,000 $<0,05$. Hingga dapat di simpulkan bahwa hipotesis H3 diterima.Yang artinya variabel 7-day Reserve Repo RateBank Indonesia dan Nilai Tukar Rupiahberpengaruh positif terhadap Profitabilitas Perbankan Priode 2017-2019.

\section{c. Uji Koefisien Determinasi}

Uji Koefisien Determinasi merupakan pengujian yang bertujuan untuk mengetahui seberapa besar kontribusi variabel independen (X) dapat mempengaruhi variabel dependen (Y).Untuk mengetahui hasil Uji Koefisien Determinasi dapat dilihat pada kolom Adjusted $R$ Square. Adapun hasil uji koefisien determinasi dapat dilihat pada tabel 1.8 dibawah ini:

Tabel 1.8

Hasil Uji Koefisien Determinasi

Website: http://jurnal.radenfatah..ac.id/index.php/ieconomics 


\begin{tabular}{|l|c|r|r|r|}
\multicolumn{7}{c|}{ Model Summary $^{b}$} \\
\hline $\begin{array}{l}\text { Mode } \\
\perp\end{array}$ & $R$ & R Square & $\begin{array}{c}\text { Adjusted R } \\
\text { Square }\end{array}$ & $\begin{array}{c}\text { Stdd. Error of } \\
\text { the Estimate }\end{array}$ \\
\hline 1 & $.590^{\mathrm{a}}$ & .348 & .325 & 41.12381 \\
\hline
\end{tabular}

Sumber: SPSS Data diolah

Dari hasil UjiKoefisien Determinasi pada tabel 1.3 diatas dapat dilihat bahwa nilai Adjusted $R$ Square sebesar 0,325 atau 32,5\% . Nilaitersebut menunjukkan bahwa Profitabilitas Perbankan selama priode 2017-2019 dipengaruhi oleh variabel 7-day Reserve Repo RateBank Indonesia dan Nilai Tukar Rupiahsebesar 32,5\%. sedangkan sisanya $67,5 \%$ dipengaruhi oleh variabel lain.

\section{PEMBAHASAN}

\section{Pengaruh 7-day Reserve Repo Rate Bank Indonesia Terhadap Profitabilitas Perbankan}

Berdasarkan hasil analisis dapat diketahui bahwa 7-day Reserve Repo Rate Bank Indonesia berpengaruh positif terhadap Profitabilitas Perbankan priode 2017-2019.Hasil penelitian ini mengindikasikan bahwa7-day Reserve Repo Rate merupakan instrumen moneter yang digunakan BI untuk memudahkan merefleksikan kebijakannya di pasar keuangan.Instrumen baru ini mendekatkan jarak antara suku bunga pasar uang dengan suku bunga kebijakan.Selain itu, instrumen 7-day Reserve Repo Rate juga ditujukan untuk memperdalam pasar keuangan di Indonesia.Dengan memperdalam kondisi pasar keuangan di Indonesia, aktivitas di pasar keuangan menjadi lebih sering.Kelebihan uang di BI dapat dialihgunakan sehingga pasar keuangan makin dalam karena mereka bergerak di waktu jangka pendek.Upaya ini juga diharapkan bisa menjadi model bagi perbankan.Karena untuk kepentingan interaksi keuangan antar bank, maka BI 7-Day Repo Rate bisa digunakan sebagai acuan perbankan.Dengan begitu, diharapkan kecenderungan bank meminjam atau menyimpan uang di BI menurun. Mereka akan lebih interaktif melalui transaksi Repo dan Reverse Repo sesuai acuan BI 7-Day Reverse Repo.

\section{Pengaruh Nilai Tukar Rupiah Terhadap Profitabilitas Perbankan}

Website: http://jurnal.radenfatah..ac.id/index.php/ieconomics 
Berdasarkan hasil analisis dapat diketahui bahwa Nilai Tukar Rupiah berpengaruh positif terhadap Profitabilitas Perbankan priode 2017-2019. Hasil penelitian ini mengindikasikan bahwa apabila nilai tukar mengalami gejolak terhadap rupiah maka akan berdampak pada profitabilitas perbankan. Artinya bahwa jika nilai mata uang domestic lebih tinggi daripada uang asing maka akan menurunkan harga-harga impor. Dengan menurunnya harga dapat berpotensi meningkatkan prekonomian pada sektor rill yang dengan sendirinya akan mendorong masyarakat untuk berinvestasi pada sektor tersebut. Perbankan dalam hal ini memberikan dana bantuan terhadap permodalan bagi masyarakat yang bergerak pada bidang inverstasi dan keuntungan yang didaptkan oleh perbankan adalah peningkatan profitabilitas perbankan.

\section{SIMPULAN}

Berdasarkan hasil penelitian dapat disimpulkan bahwa dari hasil uji asumsi klasik, terdapat data terdistribusi secara normal dan tidak terdapat masalah Multikolinieritas dan Heteroskedastisitas. Adapun dari hasil uji regresi linier berganda dapat di seimpulkan bahwa variabel 7-day Reserve Repo Rate Bank Indonesia dan Nilai Tukar Rupiah berpengaruh positif terhadap Profitabilitas Perbankan priode 2017-2019 baik secara parsial dan secara simultan. Sedangkan hasil uji koefisien determinasi variabel 7-day Reserve Repo Rate Bank Indonesia dan Nilai Tukar Rupiah dapat mempengaruhi Profitabilitas Perbankan priode 2017-2019 sebesar 32,5\%. Sedangkan sisanya dipengaruhi dari luar penelitian yang tidak dapat peneliti sebutkan.

\section{DAFTAR PUSTAKA}

Athanasoglou, Panayiotis P., Sophocles N. Brissimis, and Matthaios D. Delis. "Bank-Specific, Industry-Specific and Macroeconomic Determinants of Bank Profitability." Journal of International Financial Markets, Institutions and Money 18, no. 2 (April 1, 2008): 121-136.

Dwijayanthy, Febrina, and Prima Naomi. "Analisis Pengaruh Inflasi, BI Rate, Dan Nilai Tukar Mata Uang Terhadap Profitabilitas Bank Periode 2003-2007 [English: Analysis

Website: http://jurnal.radenfatah..ac.id/index.php/ieconomics 
of Effect of Inflation, BI Rate, and Exchange Rate on Bank Profitability (Period 20032007)]." Jurnal KARISMA 3, no. 2 (April 1, 2009): 87-98.

Hidayati, Amalia Nuril. "Pengaruh Inflasi, Bi Rate Dan Kurs Terhadap Profitabilitas Bank Syariah Di Indonesia." An-Nisbah: Jurnal Ekonomi Syariah 1, no. 1 (October 10, 2014): 72-97.

Karim, Adiwarman, 2008, Ekonomi Makro Islam, Jakarta: PT Raja Grafindo Persada.

Kasmir, 2016, Bank dan Lembaga Keuangan Lainnya, cet.17 Jakarta: Rajawali Pers.

Marwansyah, Sofyan, and Sri Rusiyati. "Dampak Kebijakan BI Rate Repo 7 Days terhadap Kinerja Bank Pemerintah." Jurnal Ecodemica: Jurnal Ekonomi, Manajemen, dan Bisnis 3, no. 2 (September 9, 2019): 248-256.

Syamsuddin, Lukman, 2000, Manajmen Keuangan Perusahaan, Jakarta: PT Raja Grafindo Persada.

Widodo, Slamet, Robby Alexander Sirait, S Si, Marihot Nasution, and Ade Nurul Aida. "Dr. Asep Ahmad Saefuloh, S.E., M.Si." buletin APBN 01, no. 17 (2016): 12.

Wulandari, Debby, Pengaruh Tingkat Suku Bunga, Pertumbuhan Ekonomi (PDB) dan Return on Asset (ROA) Terhadap Investasi Saham Syariah, Skripsi, UIN Sunan Kalijaga Yogyakarta, 2016.

Website: http://jurnal.radenfatah..ac.id/index.php/ieconomics 